\title{
Forest moth assemblages as indicators of biodiversity and environmental quality in a temperate deciduous forest
}

\author{
JeONG-Seop AN and SeI-Woong CHOI* \\ Department of Environmental Education, Mokpo National University, Muan, Jeonnam 534-729, South Korea; \\ e-mails: naneon@nate.com; choisw@mokpo.ac.kr
}

Key words. Moth, biodiversity, indicators, abundance, richness, temperate deciduous forest, elevation, season

\begin{abstract}
The aim of the present study was to find groups of moths suitable for estimating changes in the abundance and richness of local and regional biodiversity in a temperate forest. We captured macro-moths from May to October over a 5-year period (2005-2009) at various sites in Mt. Jirisan National Park (JNP) in southern Korea. Six taxa were selected based on a strong correlation between the number of species in these taxa and total number of species of large moths: Ennominae (Enn), Arctiinae (Arc), Hermininae (Her), Notodontidae (Not), Drepanidae (Dre) and Ophiderinae (Oph). Of these, combinations of four groups were found to have the best predictive capability. We determined whether these indicator groups could be used to reveal mean differences in species abundance according to spatial (forest type, altitude) and temporal variables (monsoon season) since moth composition and abundances were closely related with these variables. The mean differences in the groups of moths in the two types of forest (Arc, Dre, Enn, Not), two altitudes (Dre, Enn, Her, Oph) and two seasons (Dre, Enn, Oph) were significant. Overall, it was revealed that a set of four groups, including two taxa (Dre and Enn), could be used to show differences in local and regional biodiversity of moths in southern Korean temperate forest.
\end{abstract}

\section{INTRODUCTION}

Insects comprise approximately two-thirds of known organisms in the world and are viewed as good indicators of ecosystem biodiversity because they are abundant, diverse and adapted to different environmental conditions (Samways, 1994). Insect ecological monitoring is important for several reasons (Spellerberg, 2005). First, many ecosystems and communities remain poorly understood and data gathered in the process of monitoring can add substantially to our knowledge of these systems. Long-term data are also needed to understand how human-induced change is affecting insect diversity and the environment. In addition, information gathered from monitoring can be used as an early warning system to alert conservationists to the types and sizes of changes of significant concern and catalyze political and management action to retard or prevent adverse changes. Monitoring also provides information that can be used to better understand the implications of a changing environment for the things we care about; i.e., insect biodiversity and our quality of life (Spellerberg, 2005).

Given that more than $80 \%$ of the species on Earth have not yet been described (Hawksworth \& Kalin-Arroyo 1995), the importance of biodiversity indicators in conservation is pivotal and their use constitutes one of the basic tools of conservationists for quick action against biodiversity loss (Caro \& O’Doherty, 1999; Lindenmayer et al., 2000; Soberon et al., 2000). Conservation practitioners attempt to identify taxa that are well known, can be readily surveyed and have the potential to be used as indicators of the distribution patterns of other un-surveyed taxa or of overall biodiversity at different spatial scales (Noss, 1990; McGeoch, 1998). If such indicators can be established, this eliminates the need for biodiversity surveys, which are expensive and time-consuming, particularly in cases where the biota is not well known or described. Therefore, the use of indicators can greatly simplify the steps required for making good ecosystem management decisions (Kati et al., 2004).

The validity of using biodiversity indicators for different taxa has been widely debated. Several researchers record a positive correlation of species richness across taxa among vascular plants, tiger beetles and butterflies, and suggest the use of a specific group as an indicator (Pearson \& Cassola, 1992; Crisp et al., 1998; Pearson \& Carroll, 1998; Pharo et al., 1999). In contrast, other researchers record only weak indicator relationships across different taxa (Saetersdal et al., 1993; Van Jaarsveld et al., 1998; Part \& Soderstrom, 1999; Ricketts et al., 1999; Vessby et al., 2002) and suggest their combined use as biodiversity indicators. These contrasting results indicate that the adoption of biodiversity indicators across taxa requires rigorous testing before implementation (Gustafsson, 2000).

Lepidoptera are one of the most diverse groups of insects, with more than 157,000 species described worldwide (van Nieukerken et al., 2011). They are noteworthy for their wings, which are often vividly coloured and have a multiplicity of forms, facilitating identification. These insects are also major herbivores, thereby linking primary producers and consumers in ecosystems (Scoble, 1995). A typical lepidopteran insect community has (1) a species

\footnotetext{
* Corresponding author.
} 
TABLE 1. Review of taxa of Lepidoptera selected as indicators of the biodiversity and environmental conditions in temperate and tropical forests.

\begin{tabular}{|c|c|c|c|c|c|c|c|}
\hline \multirow{2}{*}{$\begin{array}{l}\text { Moth } \\
\text { assemblage }\end{array}$} & \multirow{2}{*}{$\begin{array}{l}\text { Taxonomic } \\
\text { level }\end{array}$} & \multirow[b]{2}{*}{ Biome } & \multicolumn{4}{|c|}{ Predictor } & \multirow[b]{2}{*}{ References } \\
\hline & & & $\begin{array}{l}\text { Species } \\
\text { richness }\end{array}$ & Elevation & $\begin{array}{l}\text { Habitat } \\
\text { quality }\end{array}$ & $\begin{array}{c}\text { Habitat } \\
\text { disturbance }\end{array}$ & \\
\hline \multirow{3}{*}{ Arctiinae } & Subfamily & Temperate & $\mathrm{v}$ & & & $\mathrm{v}$ & $\begin{array}{c}\text { Burford et al. (1999) } \\
\text { Summerville et al. (2004) }\end{array}$ \\
\hline & Subfamily & Tropical & & & & $\mathrm{v}$ & Kitching et al. (2000) \\
\hline & Tribe & Tropical & & & $\mathrm{v}$ & & Hilt \& Fiedler (2006) \\
\hline \multirow{3}{*}{ Geometridae } & Subfamily & Tropical & & & $\mathrm{v}$ & & Axmacher et al. (2004) \\
\hline & Family & Tropical & & $\mathrm{v}$ & & $\mathrm{v}$ & Beck \& Chey (2007) \\
\hline & Subfamily & Tropical & & & & $\mathrm{v}$ & $\begin{array}{l}\text { Kitching et al. (2000) } \\
\text { Brehm \& Fiedler (2005) }\end{array}$ \\
\hline Noctuidae & Subfamily & Tropical & & & & $\mathrm{v}$ & Kitching et al. (2000) \\
\hline \multirow[t]{2}{*}{ Notodontidae } & Family & Temperate & $\mathrm{v}$ & & & & $\begin{array}{c}\text { Burford et al. (1999) } \\
\text { Summerville et al. (2004) }\end{array}$ \\
\hline & Tribe & Tropical & & & & $\mathrm{v}$ & Hilt \& Fiedler (2006) \\
\hline Pyralidae & Subfamily & Tropical & & & & $\mathrm{v}$ & Kitching et al. (2000) \\
\hline \multirow{2}{*}{ Sphingidae } & Family & Tropical & & $\mathrm{v}$ & & & Ignatov et al. (2011) \\
\hline & Subfamily & Tropical & & & & $\mathrm{v}$ & Beck et al. (2006) \\
\hline
\end{tabular}

diversity and composition that varies over broad spatial scales; (2) species dominance and evenness within a community that is determined at fine spatial scales; and (3) changes in species richness across all spatial scales, with unique species encountered at each sampling level (Summerville et al., 2004). For these reasons, moths have been widely used in ecological and conservation research worldwide (Table 1; Kitching et al., 2000; Summerville et al., 2001; Summerville \& Crist, 2002).

Mount Jirisan National Park (JNP) is the highest mountain range on the mainland of South Korea (highest peak: $1,915 \mathrm{~m}$, area: $440.517 \mathrm{~km}^{2}$ ) and the first national park established in Korea (Fig. 1). As part of the Korea LongTerm Ecological Monitoring scheme, we have been monitoring the moth populations at different altitudes and in different vegetation types. However, large numbers of moths were captured at several sites in the JNP and a substantial amount of time and expertise was needed to identify the moths. Therefore, we needed to identify surrogate taxa that could be used to track changes in moth populations in mountain forest areas such as JNP.

In the present study, our goal was to identify groups of moths (e.g. family or subfamily) that could be used to estimate the total moth biodiversity in JNP and predict changes in the local and regional biodiversity of JNP. We investigated whether a few groups of moths could be used to predict the total moth biodiversity and which combination of groups was the most suitable for estimating total species richness. After selecting indicator taxa, we determined their effectiveness in monitoring biodiversity.

\section{MATERIAL AND METHODS}

\section{Study sites and moth sampling}

Temperate weather is typical of the Mount Jirisan National Park (JNP). The annual average temperature is $12-13^{\circ} \mathrm{C}$ and annual precipitation $1,200 \mathrm{~mm}$, most of which falls in summer. The vegetation is divided into three main zones: subalpine $(>1,400 \mathrm{~m})$, cool temperate $(400-1,400 \mathrm{~m})$ and warm temperate (200-300 m on southern aspects) (Yim, 1977). Six sites in JNP were sampled for five years (2005-2009) (Fig. 1, Table 2). Site selection was based on forest type and altitude and the six sites sampled categorized in terms of these two factors. The vegetation of JNP is mainly deciduous broadleaved forest, but coniferous forests are present at high and some low altitude sites that were disturbed and artificially transformed into pine forest. The vegetation at each site was categorized as either coniferousdominant or deciduous-dominant. The vegetation at CE and AK consisted mainly of coniferous trees, namely Pinus densiflora and Abies koreana. BS, SSA, HY and QM are covered with hardwood deciduous trees (Quercus mongolica, Q. variabilis, $Q$. serrata, Stewartia pseudocamellia, Ulmus davidiana) with little understory vegetation beneath a closed canopy.

TABLE 2. Description of the sites sampled in the Mt. Jirisan National Park (JNP), South Korea.

\begin{tabular}{llccc}
\hline Site & Location & Altitude $(\mathrm{m})$ & Forest & Aspect \\
\hline CE & $35^{\circ} 16^{\prime} 36^{\prime \prime} \mathrm{N}, 127^{\circ} 28^{\prime} 41^{\prime \prime} \mathrm{E}$ & 295 & Conifer & South \\
BS & $35^{\circ} 22^{\prime} 33^{\prime \prime} \mathrm{N}, 127^{\circ} 34^{\prime} 58^{\prime \prime} \mathrm{E}$ & 518 & Mixed deciduous & North \\
SSA & $35^{\circ} 17^{\prime} 31^{\prime \prime} \mathrm{N}, 127^{\circ} 29^{\prime} 39^{\prime \prime} \mathrm{E}$ & 660 & Mixed deciduous & South \\
HY & $35^{\circ} 21^{\prime} 18^{\prime \prime} \mathrm{N}, 127^{\circ} 38^{\prime} 08^{\prime \prime} \mathrm{E}$ & 760 & Mixed deciduous & North \\
AK & $35^{\circ} 18^{\prime} 13^{\prime \prime} \mathrm{N}, 127^{\circ} 33^{\prime} 34^{\prime \prime} \mathrm{E}$ & 1320 & Conifer & North \\
QM & $35^{\circ} 18^{\prime} 02^{\prime \prime} \mathrm{N}, 127^{\circ} 33^{\prime} 09^{\prime \prime} \mathrm{E}$ & 1372 & Mixed deciduous & North \\
\hline
\end{tabular}



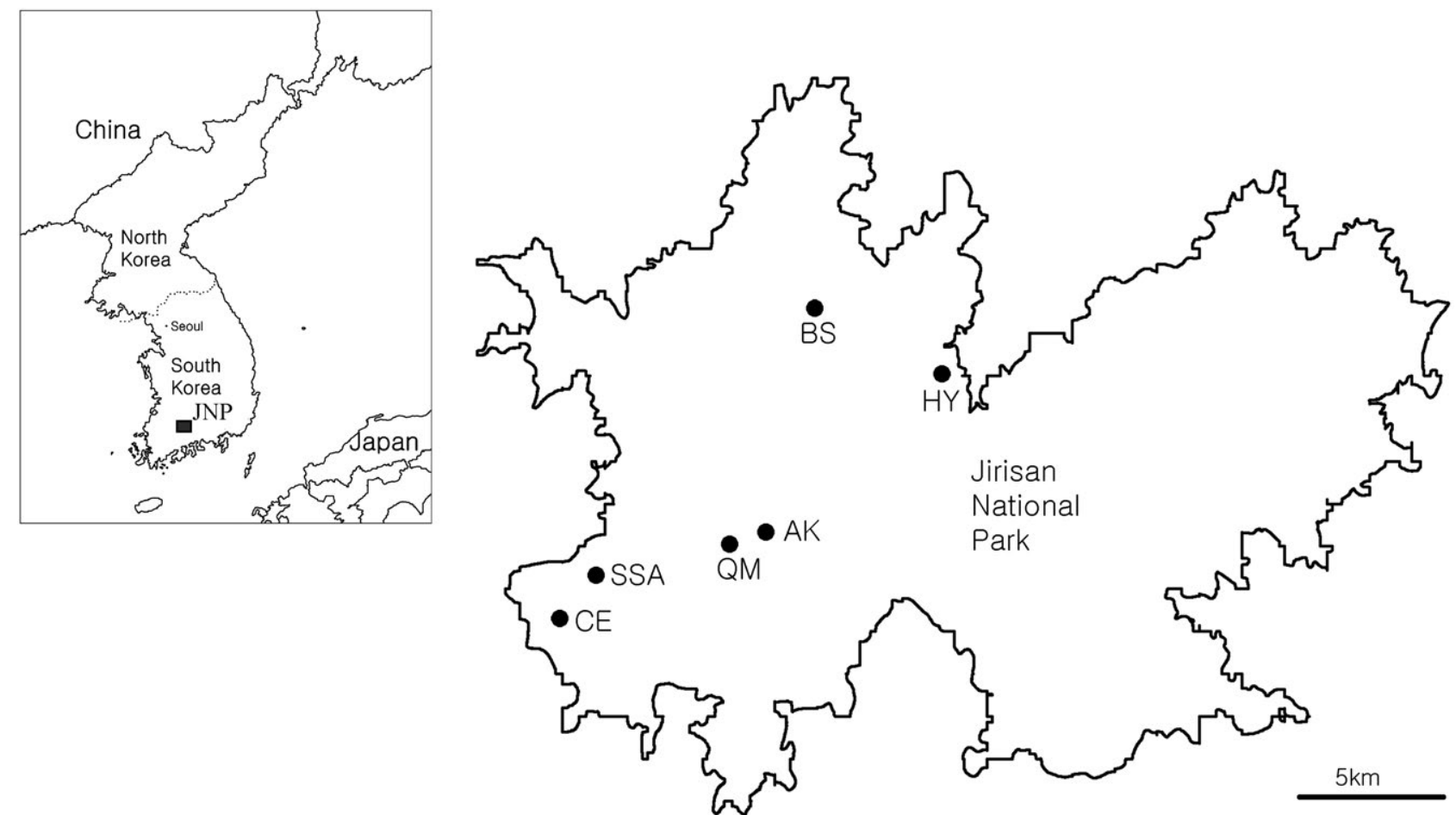

Fig. 1. Location of Mt. Jirisan National Park (JNP) in South Korea and location of the sampling sites in the National Park. See Table 1 for geographic information of sampling sites.

Of the six sites CE was the site at the lowest altitude $(295 \mathrm{~m})$ and QM at the highest altitude (1372 m) (Table 2). Altitude was found to be one of the important environmental factors associated with moth assemblages in JNP since change in altitude is closely related with many abiotic conditions such as temperature, precipitation, relative humidity, solar radiation, wind and soil condition (Choi \& An, 2010). We divided these six sites into low and high because the moth species richness showed a hump-shaped pattern with the highest peak at $760 \mathrm{~m}$ (Choi \& An, 2010).

A light trap consisting of a 22-watt ultraviolet light and a 12 $\mathrm{V}$ battery (BioQuip co., USA) was used to collect insects at each site. Moths were sampled once a month from May to October from 2005 to 2009. At each site, samples were collected 27 to 30 times (a total of 173 trap nights). This difference in the numbers of samples among the five years was caused by the failure of sampling due to coldness at the high altitude sites. We avoided the effects of weather or moonlight on moth catches at each trap by sampling simultaneously at all six sites. Moth sampling continued for six hours after dusk.

The main species of Lepidoptera included in this study belonged to 19 moth families traditionally classified in the informal category of macrolepidoptera and several more readily identifiable families of microlepidoptera (Cossidae, Limacodidae, Thyrididae, Zygaenidae). Moths were identified to species and were lodged in the entomological collection of Mokpo National University, South Korea.

Estimation of total species richness and selection of indicator taxa

We examined the current level of moth biodiversity by estimating species richness (Chao 1) at each sampling site. The Chao 1 estimator works well when samples contain a large number of rare species (Chao, 1984) and generates the sum of the observed number of species and $\mathrm{F}_{1}^{2} / 2 \mathrm{~F}_{2}$, where $\mathrm{F}_{1}$ is the number of species with a single individual (singleton) at each site and $F_{2}$ is the number of species with two individuals (doubleton) at each site. Chao 1 was calculated using EstimateS (Colwell, 2009).

To determine the most effective combination of candidate taxa we used the following three arbitrary criteria. We first screened the taxa based on their species richness (number of species) selecting those which made up more than 3\% (27 species) of the total number of species. Second, we reduced the number of candidate taxa by only keeping those taxa with a Pearson correlation value of more than 0.7 between the species richness of the candidate taxon and the total species richness. Third, we again examined the correlation value between all possible combinations of candidate taxa and total species richness. Pearson correlation analysis and group comparisons using the Wilcoxon test were performed using the SPSS software package (SPSS Inc., 2009).

\section{RESULTS}

A total of 18,447 individuals and 903 species in 19 families were captured from May to October over a period of 5 years (2005-2009) (Table 3). Moth species richness and abundance were the highest at HY (533 species and 3,809 individuals), followed by BS (532 species and 3,662 individuals) and then SSA (432 species and 3,329 individuals). Species richness of Noctuidae was highest, with 398 species and 6,883 individuals, followed by Geometridae (295 species and 7,337 individuals) and Notodontidae (58 species and 1,032 individuals) (Table 2). Because Noctuidae and Geometridae were speciesrich groups, we divided them into subfamilies based on Kononenko et al. (1998) and Kim et al. (2001). The rarefaction curves indicated that the estimated species richness at most sites was asymptotic (Fig. 2), suggesting that 
TABLE 3. Summary of the number of species (individuals in parenthesis) of moths collected from 2005 to 2009 at six different sites in Mt. Jirisan National Park. Bold indicates the 11 taxa selected on the basis of the high number of species collected (more than $3 \%$ of the total number of species).

\begin{tabular}{|c|c|c|c|c|c|c|c|}
\hline Family / Subfamily & $\mathrm{CE}$ & $\mathrm{BS}$ & SSA & HY & $\mathrm{AK}$ & QM & TOTAL \\
\hline BOMBYCIDAE & $1(1)$ & $3(8)$ & $1(2)$ & $2(4)$ & - & $1(2)$ & $3(17)$ \\
\hline BRAHMAEIDAE & - & $1(1)$ & - & $2(2)$ & - & - & $2(3)$ \\
\hline Cossidae & - & - & $1(1)$ & - & - & - & $1(1)$ \\
\hline DREPANIDAE & $12(44)$ & $17(178)$ & $17(274)$ & $16(154)$ & $18(86)$ & $14(73)$ & $28(809)$ \\
\hline ENDOMIDAE & - & - & - & $1(2)$ & $1(5)$ & $1(2)$ & $1(9)$ \\
\hline EPIPLEMIDAE & $2(25)$ & $1(3)$ & $1(1)$ & $1(1)$ & - & - & $2(30)$ \\
\hline \multicolumn{8}{|l|}{ GeOMETRIDAE } \\
\hline Ennominae & $52(511)$ & $96(965)$ & $85(844)$ & 97 (999) & $57(744)$ & $62(601)$ & $138(4664)$ \\
\hline Geometrinae & $11(21)$ & $16(43)$ & $11(59)$ & $13(69)$ & $6(13)$ & $7(23)$ & $26(228)$ \\
\hline Larentiinae & $12(272)$ & 37 (179) & $30(133)$ & $62(443)$ & $33(267)$ & $32(196)$ & $96(1490)$ \\
\hline Oenochrominae & - & - & - & - & $1(1)$ & - & $1(1)$ \\
\hline Sterrhinae & $16(120)$ & $21(358)$ & $16(203)$ & $16(149)$ & $5(79)$ & $3(45)$ & $34(954)$ \\
\hline LASIOCAMPIDAE & $4(17)$ & $4(15)$ & $6(34)$ & $6(61)$ & $3(23)$ & $4(26)$ & $10(176)$ \\
\hline LiMACODIDAE & $6(23)$ & $8(44)$ & $6(31)$ & $8(47)$ & $4(13)$ & $4(39)$ & $11(197)$ \\
\hline \multicolumn{8}{|l|}{ EREBIDAE } \\
\hline Arctiinae & $12(35)$ & $13(92)$ & $16(230)$ & $19(258)$ & $11(204)$ & $9(194)$ & $29(1013)$ \\
\hline Lymantriinae & $11(18)$ & $16(100)$ & $14(237)$ & $18(93)$ & $6(14)$ & $3(16)$ & $24(478)$ \\
\hline Hermininae & $22(94)$ & $33(473)$ & $24(234)$ & $30(449)$ & $12(708)$ & $11(987)$ & 43 (2945) \\
\hline Hypeninae & $6(19)$ & $12(36)$ & $5(11)$ & $9(19)$ & $6(16)$ & $4(12)$ & $17(113)$ \\
\hline Hypenodinae & - & $2(3)$ & - & $1(1)$ & - & - & $2(4)$ \\
\hline Rivulinae & $1(6)$ & $2(4)$ & $1(1)$ & $2(3)$ & - & - & $4(14)$ \\
\hline Catocalinae & $6(8)$ & $12(39)$ & $13(30)$ & $10(78)$ & $2(4)$ & $3(15)$ & $20(174)$ \\
\hline \multicolumn{8}{|l|}{ Noctuidae } \\
\hline Acontiinae & 19 (197) & $28(174)$ & $20(84)$ & $23(99)$ & $4(56)$ & $8(108)$ & $42(718)$ \\
\hline Acronictinae & $6(43)$ & $14(43)$ & $10(127)$ & $15(42)$ & $11(34)$ & $13(34)$ & $27(323)$ \\
\hline Agaristinae & $1(1)$ & $2(8)$ & $3(26)$ & $2(58)$ & $1(1)$ & - & $3(94)$ \\
\hline Amphipyrinae & $25(74)$ & $41(143)$ & $29(97)$ & $36(133)$ & $20(46)$ & $24(60)$ & $79(553)$ \\
\hline Chloephorinae & $2(2)$ & $8(30)$ & $6(56)$ & $7(30)$ & $3(4)$ & $3(5)$ & $9(127)$ \\
\hline Cuculliinae & $3(12)$ & $10(56)$ & $8(73)$ & $8(49)$ & $6(136)$ & $7(131)$ & $19(457)$ \\
\hline Hadeninae & $5(57)$ & $14(28)$ & $8(12)$ & $8(33)$ & $5(25)$ & $10(53)$ & $21(208)$ \\
\hline Heliothinae & $1(5)$ & - & $1(2)$ & $1(1)$ & $1(1)$ & $1(1)$ & $2(10)$ \\
\hline Noctuinae & $7(11)$ & 17 (176) & $10(41)$ & $23(84)$ & $16(99)$ & $20(155)$ & $32(566)$ \\
\hline Ophiderinae & $20(133)$ & $30(151)$ & $15(52)$ & 29 (116) & $4(10)$ & $9(14)$ & $53(476)$ \\
\hline Pantheinae & $1(3)$ & $2(11)$ & $3(7)$ & $1(2)$ & $3(9)$ & $3(11)$ & $5(43)$ \\
\hline Plusiinae & $1(1)$ & $8(17)$ & $3(6)$ & $8(10)$ & $3(6)$ & $7(10)$ & $15(50)$ \\
\hline Sarrothripinae & $1(2)$ & $2(2)$ & $1(1)$ & - & - & - & $3(5)$ \\
\hline EUTELIIDAE & - & $1(1)$ & - & - & - & $1(2)$ & $2(3)$ \\
\hline Nolidae & $1(3)$ & $5(61)$ & $4(7)$ & $6(18)$ & $1(4)$ & $2(10)$ & $10(103)$ \\
\hline NotodontidAe & $16(60)$ & 35 (163) & $32(306)$ & 35 (194) & $19(135)$ & $18(174)$ & $58(1032)$ \\
\hline SaturniIdAe & $3(3)$ & $3(6)$ & $4(29)$ & $2(6)$ & $2(3)$ & $1(1)$ & $4(48)$ \\
\hline SpHINGIDAE & $1(4)$ & $14(45)$ & $14(60)$ & $12(95)$ & $7(43)$ & $7(30)$ & $20(277)$ \\
\hline THYRIDIDAE & $2(2)$ & $3(5)$ & $4(15)$ & $2(4)$ & - & - & $5(26)$ \\
\hline URANIIDAE & - & - & - & $1(2)$ & - & - & $1(2)$ \\
\hline ZYGAENIIDAE & - & $1(1)$ & $1(3)$ & $1(1)$ & - & $1(1)$ & $1(6)$ \\
\hline TOTAL & $289(1827)$ & $532(3662)$ & $423(3329)$ & $533(3809)$ & $271(2789)$ & $293(3031)$ & $903(18447)$ \\
\hline
\end{tabular}

a 5-year faunal survey at JNP was sufficient for determining species richness.

Completion of the first step in the selection of candidate taxa based on the samples collected over a period of 5 years at six sites revealed that 11 taxa comprised of more than 27 species made up $3 \%$ of the species (Table
3): Arctiinae (Arc), Drepanidae (Dre), Ennominae (Enn), Larentiinae (Lar), Sterrhinae (Ste), Acontiinae (Aco), Amphipyrinae (Amp), Hermininae (Her), Noctuinae (Noc), Ophiderinae (Oph), and Notodontidae (Not). We calculated the Pearson correlations between these 11 candidate taxa and the total number of species. 

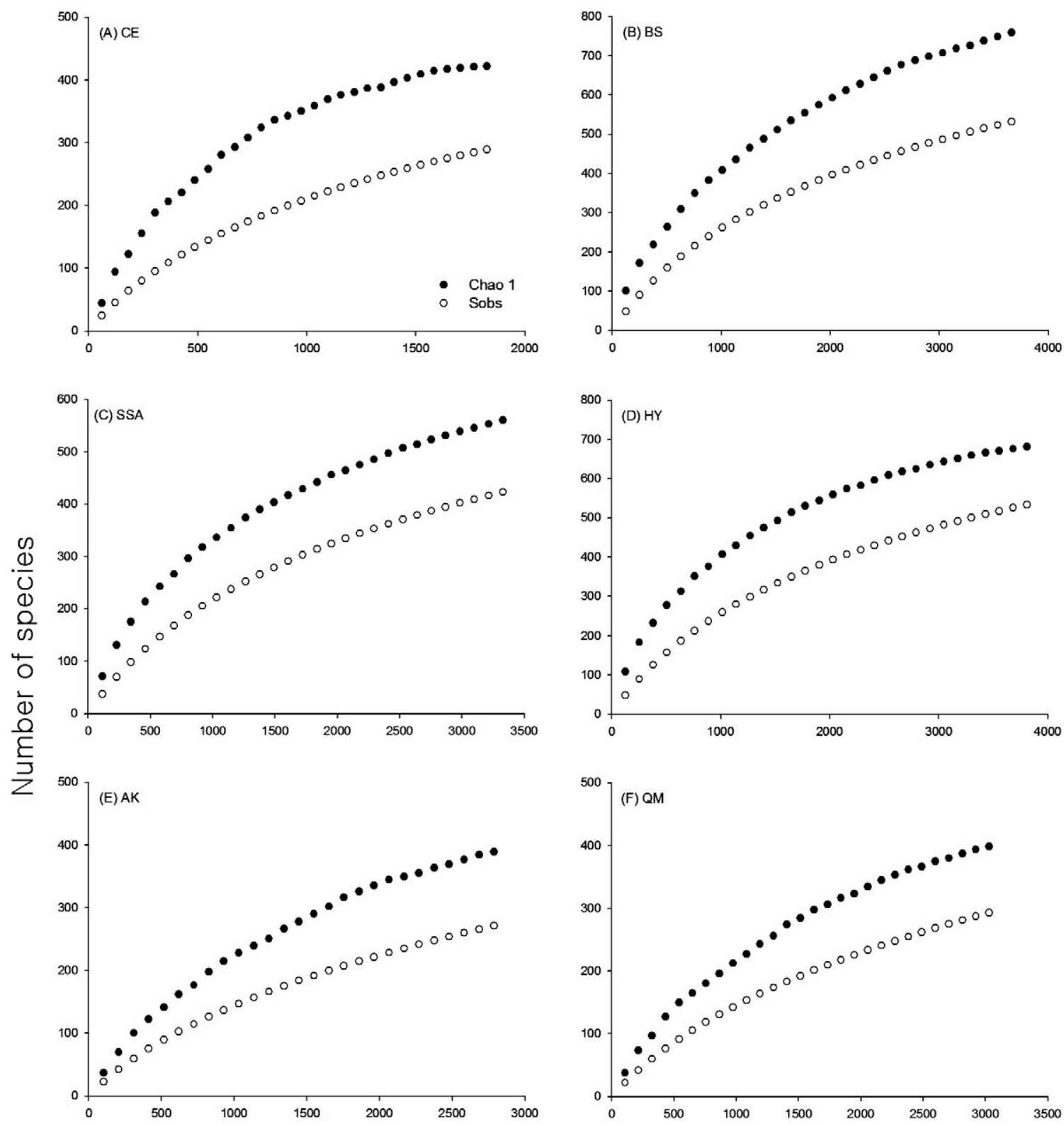

Number of individuals

Fig. 2. Rarefaction curves of observed and estimated numbers of species at six sites $(\mathrm{a}-\mathrm{f})$ in the JNP. Filled dot $(\bullet)$ indicates the species richness estimated based on Chao 1 and unfilled dot (o) indicates the observed species richness.

The next step was to reduce the number of candidate taxa; to do this we adopted a cut-off value correlation value of 0.7. As a result, six taxa were selected: Enn, Arc, Her, Not, Dre and Oph (Fig. 3). A total of 63 combinations of these six taxa were investigated to determine if there was a correlation between specific combinations of these taxa and total species richness. We determined the suitable number of candidate groups by comparing the average value of each group. When we used only a single taxon, the average correlation value was 0.789 ( $\pm \mathrm{sd}$ 0.048). An increase in the number of combinations of candidate taxa increased the average correlation value. However, the value for a combination of four taxa (average $0.949 \pm \mathrm{sd} 0.015$ ) was not statistically different from the value for a combination of five taxa (average
$0.966 \pm$ sd 0.009 ) (Fig. 4; t-test, $\mathrm{p}>0.05$ ). Therefore, we decided to use a combination of four taxa. Among the combinations of four taxa, the combination Her, Oph, Not and Enn gave the highest correlation value of 0.971 , followed by the combination Arc, Her, Not and Enn (0.967).

We determined how the biodiversity of indicator groups varied in response to spatial and temporal variables. To do this we investigated the mean differences in species abundances of these six indicator groups depending on spatial (forest type and altitude) and temporal (season) variables (Table 4). We used two sites for forest type and altitude based on site characteristics and proximity of locations. The coniferous forest sites were $\mathrm{CE}$ and $\mathrm{AK}$ and the mixed deciduous forest sites were SSY and QM. The high altitude sites were AK and QM 


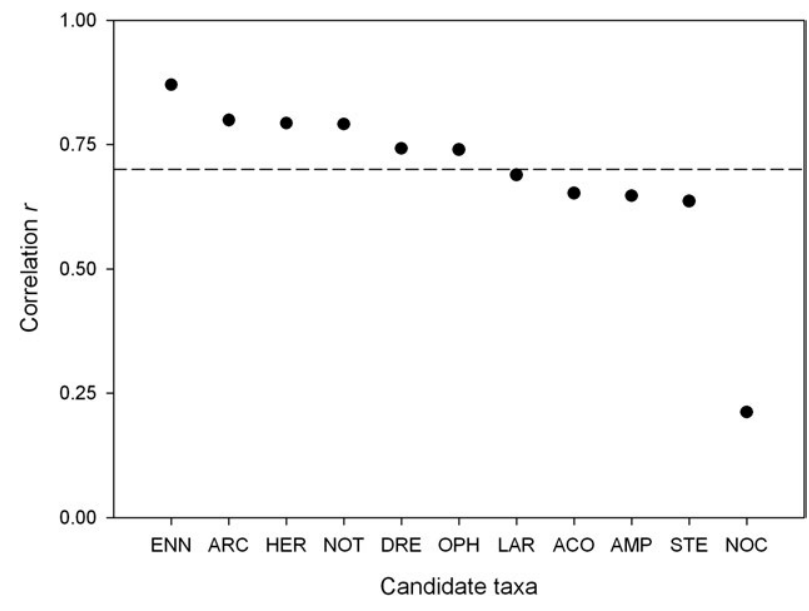

Fig. 3. Pearson correlation $r$ between the selected eleven taxa and the total species richness. Cut-off line was 0.70. Arctiinae (ARC), Drepanidae (DRE), Ennominae (ENN), Larentiinae (LAR), Sterrhinae (STE), Acontiinae (ACO), Amphipyrinae (AMP), Hermininae (HER), Noctuinae (NOC), Ophiderinae $(\mathrm{OPH})$ and Notodontidae (NOT).

and the low altitude sites were CE and SSY. Early season refers to the species abundance found in May and June and late season to species abundance in August and September. The paired Wilcoxon test showed that four taxa (Arc, Dre, Enn, Not) differed statistically between forest types, while a different set of four taxa (Dre, Enn, Her, Oph) differed between altitudes and three taxa (Dre, Enn, Oph) between seasons (Table 4).

\section{DISCUSSION}

In the present study, based on 5 years of sampling moths, we estimated that the total moth biodiversity in the JNP was 903 species, belonging to 19 families (Table 3). This species richness (>900 species) represents approximately $1 / 3$ of the known number of species of Lepidoptera in South Korea (NIBR, 2008). Based on our 5-year survey, we are confident that the total moth biodiversity in the areas surveyed was recorded because the rarefaction curves used to estimate species richness were asymptotic for most of the sites (Fig. 2).

Wiens et al. (2008) suggest that the greatest value of a surrogate or group approach is that it reduces the complexity of a species-rich system to a more tractable number of dimensions for analysis, planning and management. Summerville et al. (2004) selected four moth taxa (Notodontidae, Erebidae: Catocalinae, Geometridae: Ennominae, and Arctiinae) as indicators of species richness and habitat disturbance in temperate deciduous for-

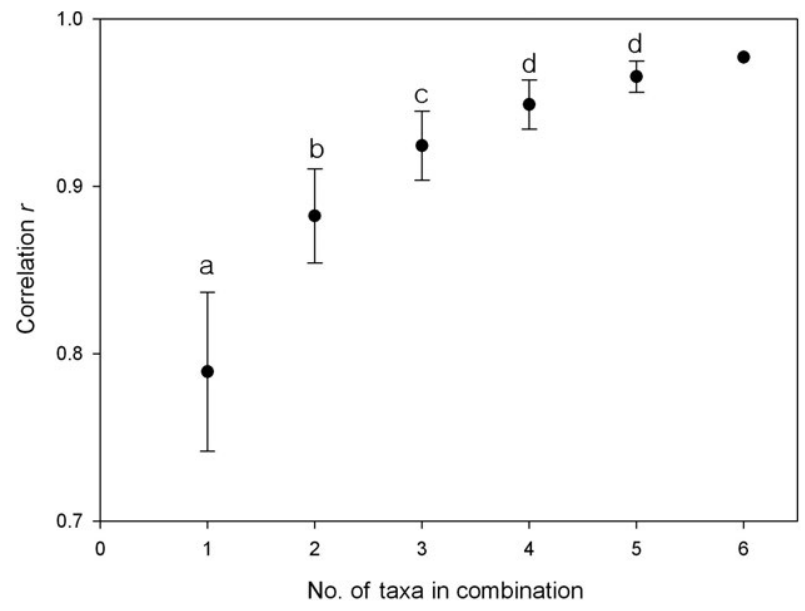

Fig. 4. Mean ( \pm standard deviation) Pearson correlation (r) of different number of taxa in combination. Different letter above each dot indicates it is significantly different (t-test, $\mathrm{p}<0.05$ ).

ests in North America. The first question addressed in the present study was how to reduce the number of moth taxa that need to be identified in the future when monitoring biodiversity. The number of taxa (19 families and 24 subfamilies) recorded at the six sites in the JNP was too large for simple biodiversity monitoring. Summerville et al. (2004) compare moth groups based on six criteria: reasonable species richness, well-known taxonomy and life history, ease of identification and sampling and habitat fidelity. However, we couldn't adopt these criteria in the present study due to lack of information (life history and habitat fidelity). Thus we adopted a few of these criteria such as species richness, taxonomy and level of identification. In addition another question addressed was how many taxa need to be identified and counted in terms of benefit (e.g., estimating total diversity) and cost (time and expertise required for identification).

In the present study, we used species richness, the correlation value and comparison of mean difference of this correlation value, to select the indicator groups. Six of the groups [Arctiinae (Arc), Drepanidae (Dre), Ennominae (Geometridae, Enn), Notodontidae (Not), Hermininae (Noctuidae, Her) and Ophiderinae (Noctuidae, Oph)] were equally diverse and abundant at all the sites surveyed (Table 3, Fig. 3) and a combination of four groups was the most economical (Fig. 4). Also, we tested the sensitivity of these indicator groups to spatial and temporal variables and showed that each candidate moth taxon was differently identified by the spatial and temporal variables and two groups (Enn, Dre) were com-

TABLE 4. Z-value of paired Wilcoxon tests of abundances of species recorded for each of the six moth groups associated with the three environmental variables. Forest type denotes the difference between conifer and mixed deciduous forest, altitude the difference between low $(<700 \mathrm{~m})$ and high altitude $(>1300 \mathrm{~m})$ and season that between before and after the monsoon. $* \mathrm{P}<0.05, * * \mathrm{P}<$ 0.005 .

\begin{tabular}{|c|c|c|c|c|c|c|}
\hline & Arctiinae & Drepanidae & Ennominae & Hermininae & Ophiderinae & Notodontidae \\
\hline Forest type & $-2.381^{*}$ & $-2.385^{*}$ & $-2.892 * *$ & -0.698 & -0.983 & $-3.664 * *$ \\
\hline Altitude & -1.250 & $-1.974 *$ & $-2.055^{*}$ & $-2.643 * *$ & $-3.178 * *$ & -1.956 \\
\hline Season & -1.391 & $-2.126^{*}$ & $-4.429 * *$ & -1.075 & $-2.745 * *$ & -1.835 \\
\hline
\end{tabular}


monly identified (Table 4). Therefore, we answered the two questions posed in the present study.

In addition, moths with large wingspans that are relatively easy to identify (Bombycidae, Brahmaeidae, Saturniidae, Sphingidae) and often sensitive to environmental change were not included in the candidate group. Beck et al. (2006) show that the diversity of sphingids in tropical regions is affected by temporal (sampling time and regime) and spatial (altitude) factors. However, in the present study none of these groups were included because they were not sufficiently abundant (e.g., one saturniid species in QM, one sphingid species in CE, no bombycid moths in AK) in the forest studied.

The six groups identified in the present study were also identified as a good indicator group in other areas (see Table 1 for review). Arctiinae (Arc) and Notodontidae (Not) are known to respond adversely to the effects of logging and habitat loss (Holloway, 1985; Burford et al., 1999; Kitching et al., 2000; Summerville et al., 2004). The numbers of two tribal groups, the Phaegopterini and Ctenuchini, are correlated with habitat disturbance and forest habitats, respectively (Hilt \& Fiedler, 2006). In the present study, we found that the abundances of Arctiinae and Notodontidae in the deciduous and conifer forests differed significantly. For example, three arctiids (Paraona staudingeri, Bizone adelina and Miltochrista striata) were more abundant in the mixed deciduous forest and one arctiid (Lithosia quadra) more abundant in the coniferous forest. Several notodontids (Lophocosma atriplaga, Peridea gigantea, Cnethodonta grisescens and Urodonta branickii) were dominant in the mixed deciduous forests and none in the coniferous forest. Although we did not examine the effect of disturbance on the numbers of species in these moth groups, it is likely that adverse changes in the forest would reduce the species abundance and richness of Arctiinae and Notodontidae.

In addition, we identified Drepanidae and Ennominae as good indicator groups in terms of high species richness and effective change due to spatial and temporal variables (Table 4). Axmacher et al. (2004) show that the assemblage of geometrid moths is closely related to the composition of the vegetation and environmental factors associated with changes in altitude. Brehm \& Fiedler (2005) record a high diversity of geometrid moths at disturbed sites. Many geometrid moths occur at disturbed sites that offer appropriate habitats for a number of species and provide early successional stage plants that are good larval food resources. However, the proportion of each subfamily differs between sites: Ennominae are low in species richness at disturbed sites but there is high species richness of Sterrhinae, Geometrinae and Larentiinae (Brehm \& Fiedler, 2005). Kitching et al. (2000) record a marked decrease in species richness in subfamilies of Geometridae (Ennominae, Geometrinae, Larentiinae and Oenochrominae) with increase in disturbance in an Australian rainforest. Our results are consistent with their findings. The composition of Ennominae was significantly associated with type of vegetation (Table 4) and several ennomines are characteristic of different altitudes:
Odontopera arida, Deileptenia ribeata, Godonela liturata, Pseudepione magnaria, and Godonela notata were abundant at the high altitude sites and Alcis angulifera, Rikiosatoa grisea, Hypomecis roboraria and Parabapta clarissa at the low altitude sites.

Drepanidae, including Thyatirinae, are easily recognizable and separable from the Noctuidae and Geometridae, and their larvae feed on trees and shrubs (Laszlo et al., 2007). Interestingly, many thyatirine moths fly during the cold period of the year and in forests at high altitudes (Laszlo et al., 2007). In the present study, four drepanid moths (Tethea ampliata, Ditrigona komarovi, Episestis nikkoensis and Nordstromia japonica) were dominant in mixed deciduous forests and Habrosyne aurorina in coniferous forest and at the high altitude sites, but Nordstromia japonica, Tethea ampliata, Episestis nikkoensis and Oreta pulchripes were highly abundant at the low altitude sites.

In addition, Hermininae and Ophiderinae showed high fidelity with altitude. For example, a detritivore noctuid moth (Hydrillodes morosa) was very abundant at high altitude, but Paracolax contigua and Paracolax pryeri were only caught at low altitude. Ophiderinae species were more abundant at the low altitude sites.

In Korea, the monsoon season lasts for a month, from late June until late July. Monsoons cause fluctuations in the moth populations before and after the monsoon season in the southern part of Korea (Choi \& Na, 2004; Park et al., 2007; An et al., 2008). Species abundances of three groups (Drepanidae, Ennominae and Ophiderinae) varied significantly with season. The life history pattern of these three groups showed an almost equal ratio of mono and bivoltine species: of the 26 species of Drepanidae, $12(47 \%)$ are univoltine and the remaining 14 bivoltine. Sixty (48\%) of 133 ennomine moths recorded are univoltine and 73 bivoltine. Twenty-five (48\%) of 53 ophiderine species recorded are univoltine and 28 bivoltine. However, all three groups were more abundant before than after the monsoon season. Previous studies in tropical and temperate forests (Kato et al., 1995; Intachat et al., 2001; Choi, 2008) show that heavy rainfall influences moth behaviour and survival by discouraging moths from flying and increasing larval and pupal mortality. Our data suggest that moth groups such as Dre, Enn and Oph in Korean temperate forests avoid the negative effects of heavy rainfall during the monsoon season by flying before the onset of the rainy season.

Finally, the use of these six groups of moths to characterize habitats needs to be validated by practical studies in diverse areas. In the future our intention is to test the utility of these groups with respect to ecological research in temperate forests in Korea.

ACKNOWLEDGEMENTS. We are grateful to members of the Environmental biology laboratory at Mokpo National University for their help in collecting moths. This study was supported by a grant from the Korea Research Foundation funded by the Korea Research Foundation (KRF- 2012R1A2A2A01003910). 


\section{REFERENCES}

An J.S., PARK M., Kang E.S. \& Chol S.W. 2008: Moth (Insecta: Lepidoptera) biodiversity on island Oenarodo, Goheung-gun. Jeonnam. - Korean J. Environ. Biol. 26: 192-202 [in Korean, English abstr.].

Axmacher J.C., Holtmann G., Scheuermann L., Brehm G., Müller-Hochenstein K. \& FiedLeR K. 2004: Diversity of geometrid moths (Lepidoptera: Geometridae) along an afrotropical elevational rainforest transect. - Divers. Distrib. 10: 293-302.

Beck J., Kitching I.J. \& Linsenmair K.E. 2006: Effects of habitat disturbance can be subtle yet significant: biodiversity of hawkmoth-assemblages (Lepidoptera: Sphingidae) in Southeast Asia. - Biodivers. Conserv. 15: 465-486.

BREHM G. \& FIEDLER K. 2005: Diversity and community structure of geometrid moths of disturbed habitat in a montane area in the Ecuadorian Andes. - J. Res. Lepid. 38: 1-14.

Burford L.S., LaCKI M.J. \& COVell C.V. JR 1999: Occurrence of moths among habitats in a mixed mesophytic forest: implications for management of forest bats. - Forest Sci. 45: 323-329.

CAro T. \& O'Doherty G. 1999: On the use of surrogate species in conservation biology. - Conserv. Biol. 13: 805-814.

CHAO A. 1984: Nonparametric estimation of the number of classes in a population. - Scand. J. Stat. 11: 265-270.

CHоI S.W. 2008: Effects of weather factors on the abundance and diversity of moths in a temperate deciduous mixed forest of Korea. - Zool. Sci. 25: 53-58.

Chor S.W. \& AN J.S. 2010: Altitudinal distribution of moths (Lepidoptera) in Mt. Jirisan National Park, South Korea. Eur. J. Entomol. 107: 229-245.

CHоI S.W. \& NA S.D. 2004: Diversity and faunal changes of the macrolepidoptera in Mt. Duryunsan and its neighboring area, Jeonnam, Korea. — Korean J. Ecol. 28: 79-83.

Colwell R.K. 2009: Estimates: Statistical Estimation of Species Richness and Shared Species from Samples. Ver. 8.2. User's guide and application published at: http://purl.oclc.org/estimates.

Crisp P., Dickinson K. \& Gibbs G. 1998: Does native invertebrate diversity reflect native plant diversity? A case study from New Zealand and implications for conservation. - Biol. Conserv. 83: 209-220.

GUSTAFSSON L. 2000: Red-listed species and indicators: vascular plants in woodland key habitats and surrounding production forests in Sweden. - Biol. Conserv. 92: 35-43.

Hawksworth D. \& Kalin-Arroyo M. 1995: Magnitude and distribution of biodiversity. In Heywood V.H. \& Watson R.T. (eds): Global Biodiversity Assessment. Cambridge University Press, Cambridge, pp. 107-192.

Hitt N. \& FiedLer K. 2006: Arctiid moth ensembles along a successional gradient in the Ecuadorian montane rain forest zone: how different are subfamilies and tribes? - $J$. Biogeogr. 33: 108-120.

HollowaY J.D. 1985: Moths as indicator organisms for categorizing rain-forest and monitoring changes and regeneration processes. In Chadwick A.C. \& Sutton S.L. (eds): Tropical Rain-Forest: The Leeds Symposium. Special Publ. of the Leeds Philosophical and Literary Society, Leeds, pp. 235-242.

Ignatov I.I., Janovec J.P., Centeno P., Tobler M.W., Grados J., Lamas G. \& Kitching I.J. 2011: Patterns of richness, composition, and distribution of Sphingid moths along an elevational gradient in the Andes-Amazon region of Southeastern Peru. - Ann. Entomol. Soc. Am. 104: 68-76.
Intachat J., Holloway J.D. \& Staines H. 2001: Effects of weather and phenology on the abundance and diversity of geometroid moths in a natural Malaysian tropical rain forest. - J. Trop. Ecol. 17: 411-429.

Kati V., Devilleres P., Dufrene M., Legakis A., Vokou D. \& LEBRUN P. 2004: Testing the value of six taxonomic groups as biodiversity indicators at a local scale. - Conserv. Biol. 18: 667-675.

Kato M., Inoue T., Hamid A.A., Nagamitsu T., Merdek M.B., Nona A.R., Itino T., Yamane S. \& Yumoto T. 1995: Seasonality and vertical structure of light-attracted insect communities in a dipterocarp forest in Sawawak. - Res. Popul. Ecol. 37: $59-79$

Kim S.S., BelJaev E.A. \& OH S.H. 2001: Illustrated Catalogue of Geometridae in Korea (Lepidoptera: Geometrinae, Ennominae). Insects of Korea, Ser. 8. Korea Research Institute of Bioscience and Biotechnology \& Center for Insect Systematics, Daejeon, 278 pp.

Kitching R., Orr A., Thalib L., Mitchell H., Hopkins M. \& Graham A. 2000: Moth assemblages as indicators of environmental quality in remnants of upland Australian rain forest. -J. Appl. Ecol. 37: 284-297.

Kononenko V.S., Ahn S.B. \& RonKay L. 1998: Illustrated Catalogue of Noctuidae in Korea (Lepidoptera). Insects of Korea, Ser. 3. Korea Research Institute of Bioscience and Biotechnology \& Center for Insect Systematics, Daejeon, 507 pp.

Laszlo G.M., Ronkay G., Ronkay L. \& Witt T. 2007: The Thyatiridae of Eurasia including the Sundaland and New Guinea (Lepidoptera). Esperiana 13: 7-220.

Lindenmayer D., Margules C. \& Botkin D. 2000: Indicators of biodiversity for ecologically sustainable forest management. - Conserv. Biol. 14: 941-950.

Margules C. \& Pressey R. 2000: Systematic conservation planning. - Nature 405: 243-253.

McGeoch M. 1998: The selection, testing and application of terrestrial insects as bioindicators. - Biol. Rev. 73: 181-201.

NIBR 2008: Biological Resources Date. National Institute of Biological Resoruces, Incheon.

Noss R. 1990: Indicators for monitoring biodiversity: a hierarchical approach. - Conserv. Biol. 4: 355-364.

Park M., OH S.G., AN J.S., Kim K.I. \& ChOI S.W. 2007: Biodiversity of Lepidopteran insects of Mt. Seungsal-san, Muan, Jeonnam, Korea. - Korean J. Environ. Biol. 25: 42-55 [in Korean, English Abstr.].

Part T. \& Soderstrom B. 1999: Conservation value of seminatural pastures in Sweden: contrasting botanical and avian measures. - Conserv. Biol. 13: 755-765.

Pearson D. \& Carroll S. 1998: Global patterns of species richness: spatial models for conservation planning using bioindicator and precipitation data. - Conserv. Biol. 12: 809-821.

Pearson D. \& Cassola F. 1992: World-wide species richness patterns of tiger beetles (Coleoptera: Cicindelidae): indicator taxon for biodiversity and conservation studies. - Conserv. Biol. 6: 376-391.

Pharo E., Beattie A. \& Binns D. 1999: Vascular plant diversity as a surrogate for bryophyte and lichen diversity. - Conserv. Biol. 13: 282-292.

Pressey R., Humphries C., Margules C., Vane-Wright R. \& Williams P. 1993: Beyond opportunism: key principles for systematic reserve selection. - Trends Ecol. Evol. 8: 124-128.

Ricketts T., Dinerstein E., Olson D. \& Loucks C. 1999: Who's where in North America? - BioScience 49: 369-381.

SAetersdal M., Line J. \& Birks H. 1993: How to maximize biological diversity in nature reserve selection: vascular plants 
and breeding birds in deciduous woodlands, Western Norway. - Biol. Conserv. 66: 131-138.

Samways M.J. 1994: Insect Conservation Biology. Chapman and Hall, London, $\mathrm{xv}+358 \mathrm{pp}$.

Scoble M.J. 1995: The Lepidoptera: Form, Function and Diversity. Oxford University Press, Oxford, 416 pp.

Soberon J., Rodriguez P. \& Vazquez-Dominguez E. 2000: Implications of the hierarchical structure of biodiversity for the development of ecological indicators of sustainable use. - Ambio 29: 136-142.

Spellerberg I.F. 2005: Monitoring Ecological Change. Cambridge Univ Press, Cambridge, $391 \mathrm{pp.}$

SPSS INc. 2009: SPSS for Windows. Ver. 17.0. SPSS Inc.

Summerville K. \& Crist T. 2002: Effects of timber harvest on forest Lepidoptera: community, guild, and species responses. Ecol. Appl. 12: 820-835.

Summerville K., Metzler E. \& Crist T. 2001: Diversity of Lepidoptera in Ohio forests at local and regional scales: How heterogeneous is the fauna? - Ann. Entomol. Soc. Am. 94: 583-591.

Summerville K., Ritter L. \& CRist T. 2004: Forest moth taxa as indicators of lepidopteran richness and habitat disturbance: a preliminary assessment. - Biol. Conserv. 116: 9-18.

Vane-Wright R., Humphries C. \& Williams P. 1991: What to protect? Systematics and the agony of choice. - Biol. Conserv. 55: 235-254.

Van Jahrsveld A., Freitag S., Chown S., Muller C., Koch S., Hull H., Bellamy C., Kruger M., Endrody-Younga S. \&
Mansell M. 1998: Biodiversity assessment and conservation strategies. Science 279: 2106-2108.

Van Nieukerken E.J., Kaila L., Kitching I.J., Kristensen N.P., Lees D.C., Minet J., Mitter C., Mutanen M., Regier J.C., Simonsen T.J., Wahlberg N., Yen S.H., Zahiri R., Adamski D., Baixeras J., Bartsch D., Bengtssin B.A., Brown J.W., Buchel S.R., Davis D.R., de Prins J., de Prins W., Epstein M.E., Gentilo-Poole P., Gielis C., Hättenschwiler P., Hausmann A., Holloway J.D., Kallies A., Karsholt O., Kawahara A.Y., Koster S., Kozlov M.V., Lafontaine J.D., Lamas G., Landry J.F., Lee S., Nuss M., Park K.T., Penz C., Rota J., Schintlmeister A., Schmidt B.C., Sohn J.C., Solis M.A., Tarmann G.M., Warren A.D., Weller S., UakovleV R.V., Zolotuhin V.V. \& Zwick A. 2011: Order Lepidoptera Linnaeus, 1758. In Zhang Z.Q. (ed.): Animal Biodiversity: An Outline of Higher-Level Classification and Survey of Taxonomic Richness. Zootaxa 3148. Magnolia Press, Auckland, pp. 212-221.

Vessby K., Soderstrom B., Glimskar A. \& Svensson B. 2002 : Species-richness correlations of six different taxa in Swedish seminatural grasslands. - Conserv. Biol. 16: 430-439.

Wiens J.A., Hayward G.D., Holthausen R.S. \& Widsom M.J. 2008: Using surrogate species and groups for conservation planning and management. - Bioscience 58: 241-252.

YIM Y. 1977: Distribution of forest vegetation and climate in the Korean Peninsula. IV. Zonal distribution of forest vegetation in relation to thermal climate. - Jpn. J. Ecol. 27: 269-278.

Received October 4, 2012; revised and accepted February 25, 2013 